\title{
Hidden-Order dan Hidden-Power pada Ruang Terbuka Publik, Studi Kasus: Lapangan Cikapundung, Bandung
}

\author{
RR. Dhian Damajani \\ Program Studi Arsitektur, Sekolah Arsitektur, Perencanaan, \\ dan Pengembangan Kebijakan, Institut Teknologi Bandung
}

\begin{abstract}
One approach to understand urban space is by observing daily activities in the public space. By identifying the complexity of events in everyday activities, we can understand how meaningful an urban space is. In order to optimize the use of public space, we can identify its use on 24 hours time-span when several actors participate in sharing roles, spaces, and time in conducting commercial activities. Results of observation indicate that hiddenorder can be identified as structured activities by order while hidden-power as controlled activities by social agreement. Both components serve as important elements for "sustaining-life" in public space.
\end{abstract}

Keywords: Cikapundung Square; everyday-urbanism; hidden order- hidden power.

\section{Pendahuluan}

Ruang publik merupakan salah satu unsur penting dalam pembahasan tentang struktur dan bentuk kota. Setiap wilayah, negara, atau kota memiliki bentuk dan karakter yang berbeda-beda. Ruang terbuka publik di Yunani, dikenal dengan nama agora; di Romawi dikenal dengan forum, di Italia dikenal dengan nama piazza/piazzeta. Ruang publik "tradisional" yang dikenal di Indonesia, di antaranya adalah alun-alun, pasar-pasar, tempat-tempat peribadatan dan jalanjalan serta jalur aksesibilitas lainnya. Ruang ini bersifat multifungsi; selain berfungsi sebagai wadah kegiatan perekonomian, juga menjadi wadah interaksi sosial dan budaya masyarakat.

Pembahasan tentang ruang publik urban yang dilakukan selama ini pada umumnya terfokus pada wujud spasialnya seperti bentuk, fungsi, tipologi, unsur estetik, dan aspek-aspek fisik lainnya. Di sisi lain, persoalan sosial perkotaan sering dibicarakan secara terpisah bahkan terlepas dari konteks spasial. Padahal, keduanya bertalian erat dan saling mempengaruhi satu sama lain. Dalam konteks perencanaan dan perancangan, seringkali ruang publik dibahas terbatas pada simbol-simbol, grafik, data statistik dan bentuk representasi lainnya. Akibatnya, persoalan yang terjadi di ruang publik kita seringkali kurang dipahami secara mendalam dan "membumi".

Received October $2^{\text {nd }} 2007$, Revised November $12^{\text {th }} 2007$, Accepted for publication December $13^{\text {th }} 2007$. 
Salah satu metoda yang saat ini diyakini mampu menjembatani hal tersebut adalah dengan mempelajari praktik-praktik keseharian di ruang publik. Everyday urbanism seperti yang dikemukakan Margaret Crawford, adalah sebuah pendekatan dalam memahami dan mendekati sebuah kota. Cities are inexhaustible and contain so many overlapping and contradictory meaning aesthetic, intellectual, physical, social, political, economic, and experientialthat can never be reconciled into a single understanding [1] Sejalan dengan hal tersebut, konsep everday life yang dikemukakan oleh Henri Lefebvre, Guy Debord, dan Michel de Certeau dianggap sebagai area yang krusial dalam kultur dan masyarakat saat ini. Ketiganya menghubungkan teori dan praktik sosial; antara pemikiran dan kehidupan sehari-hari [2] .

De Certeau membedakan dua tipe operation dalam praktik keseharian di ruang urban yaitu: strategi urban yang berdasarkan ruang, dan taktik urban yang berdasarkan waktu [3]. Menurut para pelaku sektor informal dan kelompok sosial yang pada umumnya termarjinalkan, sering menggunakan taktik urban sebagai salah satu cara dalam mempertahankan kehidupannya sekaligus cara untuk dapat "mengakses" ruang publik. Seperti yang dilakukan oleh para pelaku (aktor) yang sehari-harinya beraktivitas di ruang terbuka Lapangan Cikapundung, Bandung.

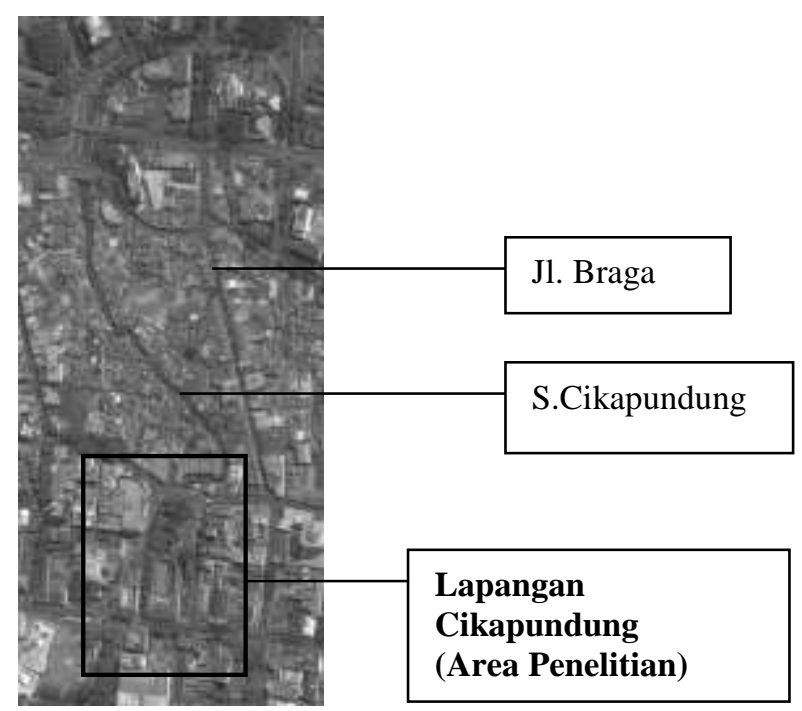

Gambar 1 Rekaman visual udara di sekitar Lapangan Cikapundung. (Sumber: http://earth.google.com) 


\section{Perencanaan Awal Kawasan di Sekitar Lapangan Cikapundung}

Lapangan tepi Sungai Cikapundung yang selanjutnya disebut dengan Lapangan Cikapundung yang dimaksud dalam penelitian ini adalah ruang terbuka yang terletak di sekitar pusat kota Bandung (Alun-Alun). Area seluas sekira $5000 \mathrm{~m} 2$ ini berbentuk setengah lingkaran yang berbatasan dengan Sungai Cikapundung di sebelah Barat, Jl. Cikapundung Timur di sebelah Timur, Jl. Asia Afrika di Sebelah Selatan dan Jl. ABC di sebelah Utaranya. Ruang terbuka yang berupa pelataran ini, dikitari oleh bangunan-bangunan penting seperti Gedung Merdeka, Hotel Homan, Gedung Percetakan Negara, dan berjarak tidak jauh dari kawasan Alun-Alun Bandung. Area ini juga berhubungan langsung dengan Jalan Braga; sebuah distrik yang menjadi salah satu ikon kota Bandung pada masa keemasannya ketika Bandung dikenal sebagai kota Parisj van Java.

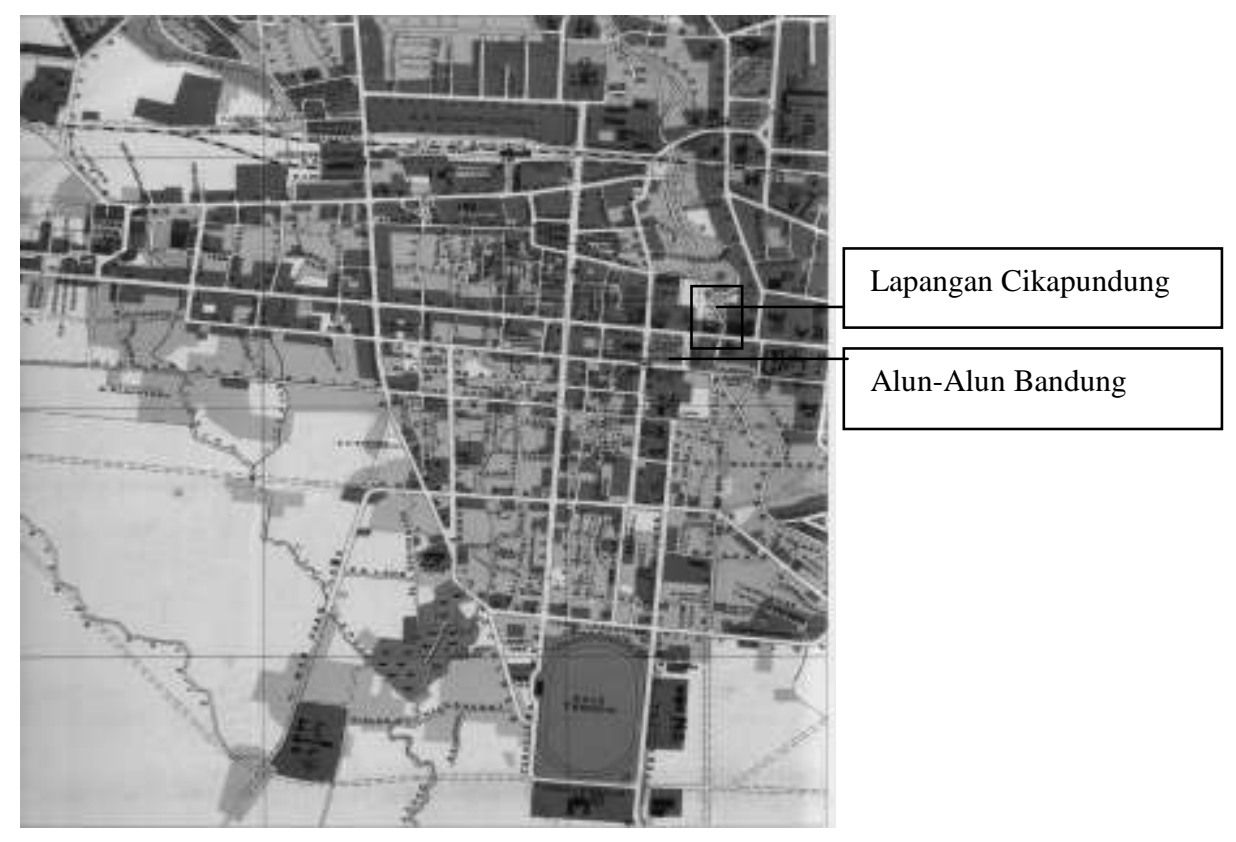

Gambar 2 Lapangan Cikapundung dalam konteks Kota Bandung tahun 1930an. (Sumber: Voskuil, 1996)

Lapangan Cikapundung sebagai salah satu area ruang terbuka publik yang berada di pusat kota Bandung (berjarak sekira 200 meter dari Alun-Alun Kota Bandung) menjadi bagian penataan kota yang dirancang oleh Pemerintahan Hindia Belanda. Area ini menjadi bagian dari hilir Sungai Cikapundung yang pada awalnya akan ditata menjadi sebuah promenade (ruang terbuka linier di 
sepanjang sungai). Namun rencana tersebut pada saat itu tidak berhasil direalisasikan, setelah hadirnya tentara Jepang yang menggantikan kekuasaan Pemerintahan Hindia Belanda pada tahun 1942-1945 [4].

Lapangan ini juga berada di tepi jalan poros utama kota saat itu (Groote Postweg) yang menunjukkan posisinya yang sangat strategis. Pada bagian utara lapangan terdapat Bragaweg yang menjadi jalan pertokoan penting dengan deretan toko-toko bagi kalangan menengah ke atas. Area ini menjadi daerah tujuan utama para pelancong dan warga Eropa yang hendak berbelanja dan berakhir pekan di Bandung.

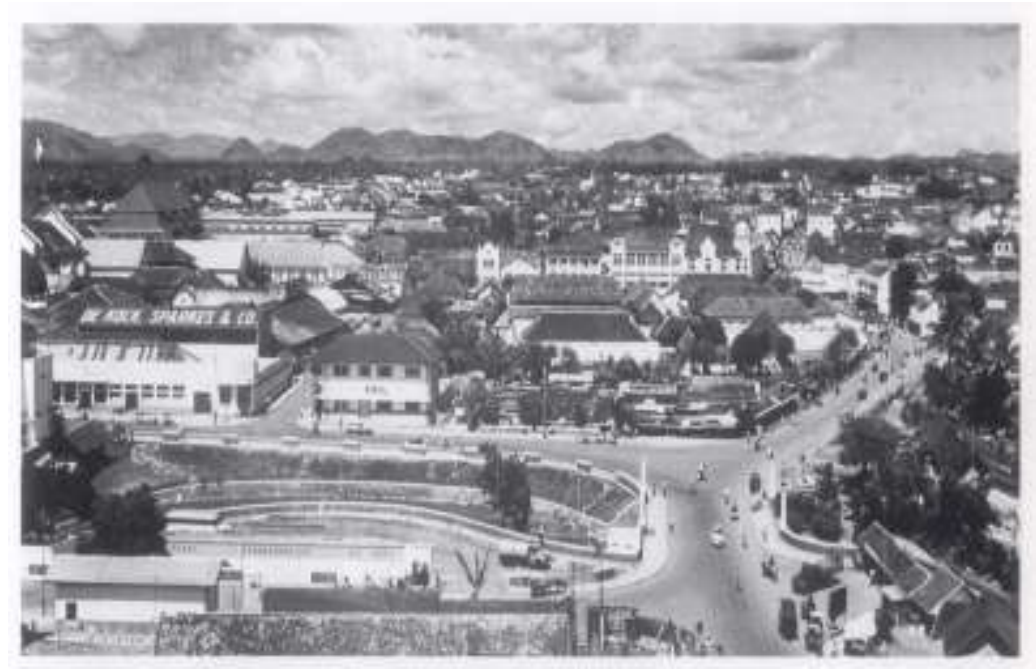

Gambar 3 Suasana di sekitar Lapangan Cikapundung pada tahun 1930an. Tampak Jl. ABC sisi kanan dan jalan-jalan lain yang masih terasa lengang. (Sumber: Voskuil, 1996)

\section{$3 \quad$ Kegiatan Keseharian di Lapangan Cikapundung}

Ilustrasi dan pembahasan berikut ini akan memperlihatkan bagaimana kegiatan ini terkonstruksi dan aktor siapa saja yang berperan di dalamnya. Terdapat 5 (lima) kegiatan utama yang secara dinamis berperan dalam kegiatan keseharian di area ini, yaitu: (1) Kegiatan "loading" koran/majalah, (2) Aktivitas perdagangan koran dan buku bekas/majalah, (3) Beragam kegiatan ekonomi pada pagi hingga siang hari, (4) Aktivitas restoran jalanan pada malam hari, dan (5) Kegiatan kantin malam terbuka. Keseluruhan kegiatan tersebut berada di area terbuka baik yang berada di Lapangan Cikapundung maupun yang berada di trotoar jalan-jalan di sekitarnya. Aktivitas yang berlangsung terus menerus dan jalin menjalin selama 24 jam ini akan dibahas dalam 5 (lima) kelompok 
waktu sebagai berikut: dini hari - pagi hari - siang hari - sore hari - malam hari.

\subsection{Kegiatan Dini Hari hingga Pagi Hari}

Lapangan Cikapundung hingga saat ini merupakan satu-satunya area tempat menampung datangnya berbagai surat kabar dan majalah baik yang diproduksi oleh penerbit di dalam kota Bandung maupun yang berasal dari luar kota Bandung. Aktivitas yang telah berlangsung sejak berpuluh tahun yang lalu ini merupakan penggerak utama yang "menghidupkan" area di sekitarnya dan mendorong terjadinya kegiatan lain.

Pada umumnya, kegiatan tersebut sudah dimulai sekira pk. 04.00 dini hari. Para agen dan loper koran serta penjual majalah baik bekas maupun baru sudah berkumpul, menempati sudut-sudut kota di sekitar lapangan. Sambil menunggu kedatangan kendaraan yang membawa surat-surat kabar tersebut, para aktor mengobrol sambil menikmati segelas kopi dan roti bakar atau ubi rebus beratapkan langit dan berselimut dinginnya pagi.

Kelompok-kelompok kecil tersebut (penjual makanan+minuman dan pembeli) membentuk ruang sosial dengan memanfaatkan trotoar, badan jalan (yang lengang karena belum ada aktivitas lain), sudut-sudut belokan jalan atau ruang di bawah pohon atau di bawah tiang lampu sebagai tempat mereka beraktivitas. Ketika koran-koran dan majalah berdatangan, suasana yang tadinya tenang berubah menjadi hiruk pikuk layaknya pasar-pasar tradisional umumnya. Beberapa kendaraan pengangkut segera dikerumuni para agen dan loper. Segera setelah masing-masing memperoleh "bagiannya", pemilahan dilakukan pada area di sekitarnya. Pada umumnya memilih trotoar atau tepian bangunan sebagai "area kerjanya". Setelah itu koran dan majalah akan diikat pada motor; kendaraan yang pada umumnya digunakan untuk beraktivitas.

Jika hari hujan, kegiatan tetap berlangsung dengan "mencari" area-area yang aman dan cukup terlindung dari air hujan, seperti halaman-halaman gedung di sekitarnya yang pada umumnya memiliki shelter/pelindung. Konfigurasi ruang secara alamiah akan berubah sesuai dengan situasi dan kondisi yang ada. Ruang fisik tidak menjadi batasan untuk tetap dapat melakukan aktivitas. Dengan kata lain, ruang fisik dapat "berubah bentuk" sesuai dengan konteksnya. "Peristiwa" yang dikonstruksi oleh para aktor menempati posisi yang lebih utama dibandingkan wujud spasialnya. Pada umumya, kegiatan tersebut akan berlangsung hingga sekira pk 06.00-06.30. Lambat laun, kepadatan ruang akan berkurang dan Lapangan Cikapundung akan kembali lengang untuk sementara. Beberapa ilustrasi suasana yang terjadi dapat dilihat pada berikut ini. 

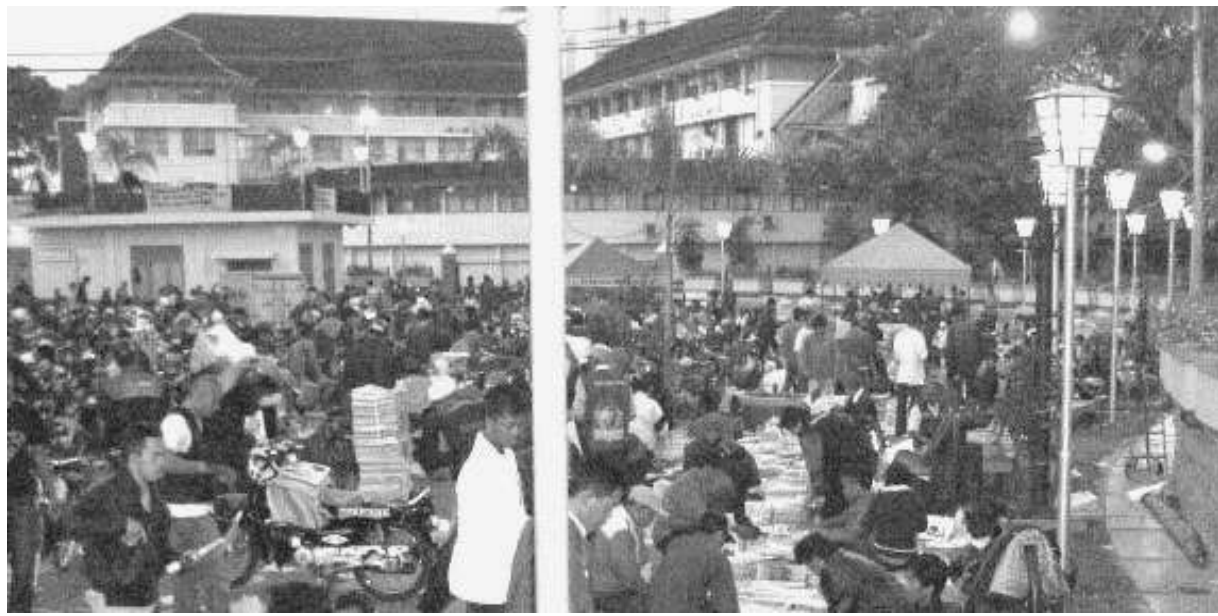

Suasana pembagian surat kabar pada agen-agen sekira pk.04.00-05.00

Lokasi Lapangan Cikapundung (foto mengarah pada Gedung PLN)

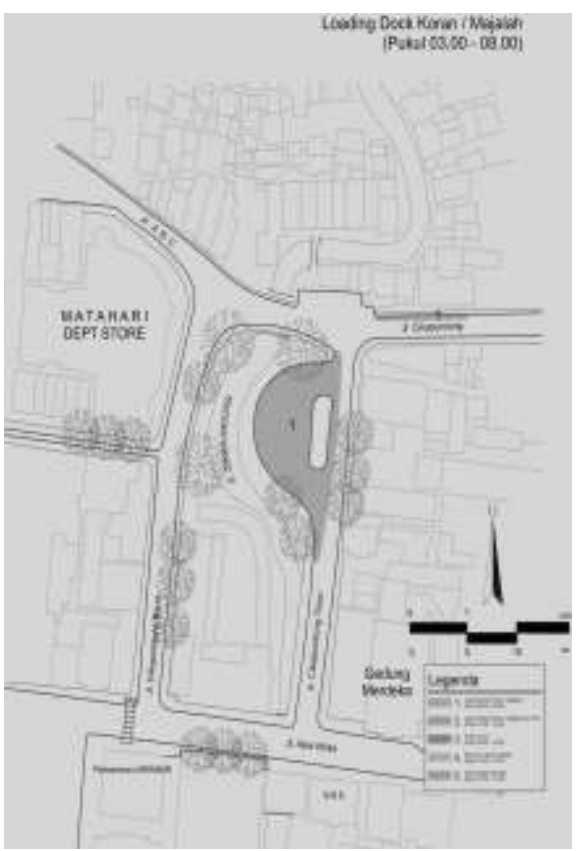

Area (1) yang diberi arsir adalah ruang terbuka yang digunakan untuk kegiatan loading surat kabar dan majalah
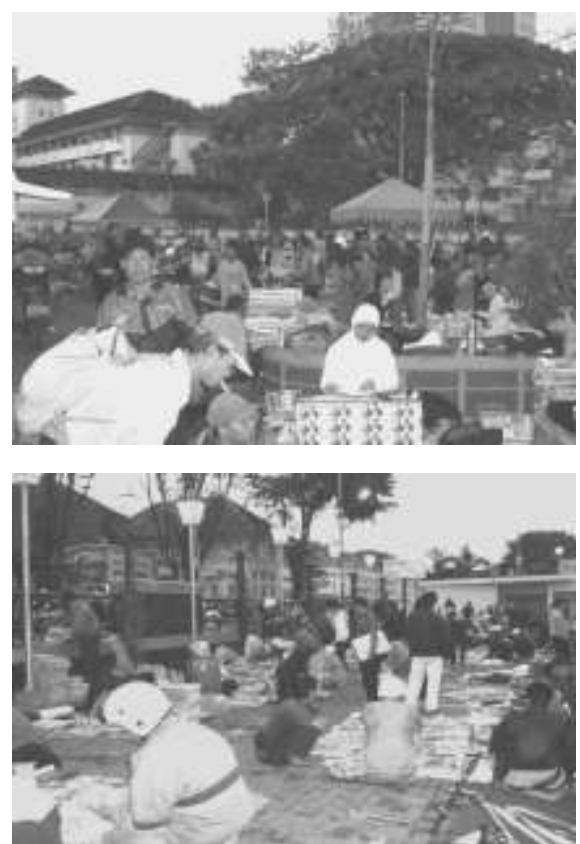

Suasana menjelang terbit matahari sekira pk.5.30. Kerumunan semakin berkurang kepadatannya.

Gambar 4 Kegiatan loading koran/majalah. Kegiatan ini tidak pernah berpindah tempat sejak awal aktivitas berlangsung. 


\subsection{Kegiatan pada Pagi hingga Siang Hari}

Menjelang matahari terbit, bersamaan dengan menghilangnya kerumunan para loper koran dan penjual majalah, Lapangan Cikapundung terlihat lengang. Ruang tersebut sementara menjadi "ruang kosong"; dan akan segera beralih fungsi. Setelah ruang dibersihkan, menjelang pk. 08.00 area tersebut berubah fungsinya menjadi area parkir khususnya bagi kendaraan para karyawan yang bekerja di kantor-kantor sekitar Lapangan Cikapundung

Ruang terbuka berupa badan jalan di sekitarnya juga difungsikan sebagai area parkir untuk memenuhi kebutuhan karena adanya berbagai fasilitas komersial. Menjelang pk. 10.00 saat aktivitas komersial dimulai, kepadatan di sekitar area khususnya jalan-jalan di sekitarnya akan meningkat. Aktor berganti; pada rentang waktu ini para petugas parkir mendapat kesempatan untuk mengendalikan ruang sekaligus "mengambil manfaat" dari keberadaan ruang tersebut melalui perannya sebagai petugas parkir.

Kesibukan tidak hanya terjadi pada badan-badan jalan, tetapi juga di sebagian besar trotoar. Fungsi trotoar tidak hanya digunakan sebagai area bagi pejalan kaki, namun digunakan pula sebagai area tempat berjualan oleh: penjual buku/majalah bekas, penjual jasa pembuatan grafir, dan pedagang kaki lima berupa kios-kios yang pada umumnya menjual kebutuhan sehari-hari, seperti minuman, makanan, tissue, sandal jepit, mie instan, sabun, pasta gigi, dan lainlain.

Salah satu "ciri khas" area ini adalah perdagangan buku bekas/majalah yang sudah lama dikenal terutama oleh warga kota yang sudah lama tinggal di Kota Bandung. Kegiatan ini berlangsung sejak pagi hari setelah aktivitas "loading" yang berakhir sekira jam 06.00 -07.00 pagi. Menjelang matahari terbit, para agen dan loper koran segera bergegas untuk mengantarkan koran dan majalah kepada para pelanggannya.

Para aktor ini memanfaatkan trotoar sebagai area tempat berjualan (lapak). Buku, majalah, baik yang masih baru maupun yang sudah bekas mulai ditata. Unsur pembentuk spasialnya berupa dinding bangunan/gedung yang berfungsi sebagai raknya dan rimbunnya dedaunan pepohonan menjadi shelter (pelingkup) yang berfungsi memberikan keteduhan. Trotoar yang telah diberi alas plastik berfungsi sebagai alas dagangan dan pengunjung yang datang menjadi bagian dari aktor yang turut berperan mengkonstruksi ruang (sosial) tersebut. "Area" antara satu penjual dengan penjual lainnya ditentukan berdasarkan kesepakatan. Tidak ada pembatas masif di antaranya. Selain itu, wujud spasial ruang ini juga disesuaikan dengan situasi di sekitarnya. "dinding pelindung pohon" setinggi $50 \mathrm{~cm}$ difungsikan sebagai tempat duduk bagi 
pembeli. Aktivitas yang berada di ruang terbuka ini tentu rentan terhadap cuaca, terutama jika hari hujan. Sebagian penjual akan "mencari" sudut-sudut yang "memungkinkan" di sekitar area; namun tidak jarang pula yang memilih untuk tidak berjualan pada hari itu. Saat kegiatan berakhir, gerobak yang berfungsi sebagai tempat penyimpanan, akan diletakkan pada sudut-sudut/celah dinding bangunan atau pagar di sekitar area.

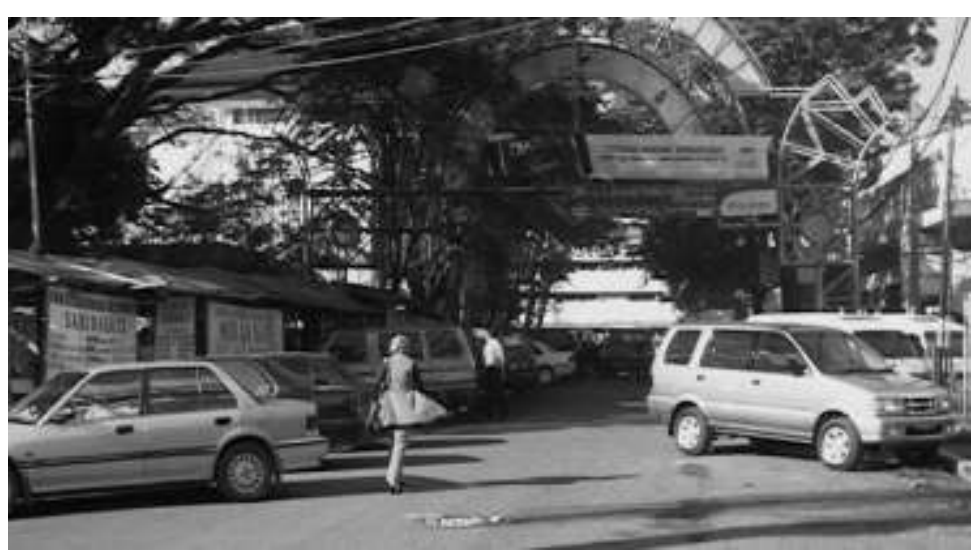

Pada pagi hari area di dalam dan di sekitar lapangan Cikapundung digunakan sebagai parkir. Lokasi : Jl Cikapundung Barat (foto mengarah pada Gedung MIRAMAR)

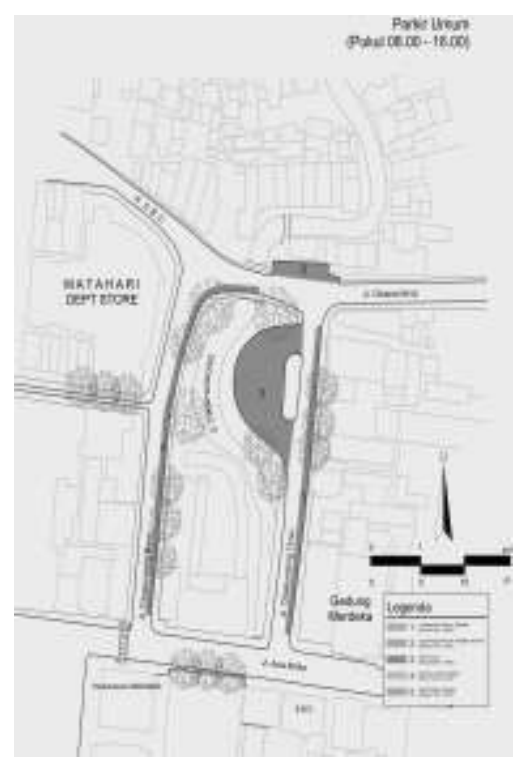

Area yang diberi arsir adalah lokasi tempat kegiatan berlangsung
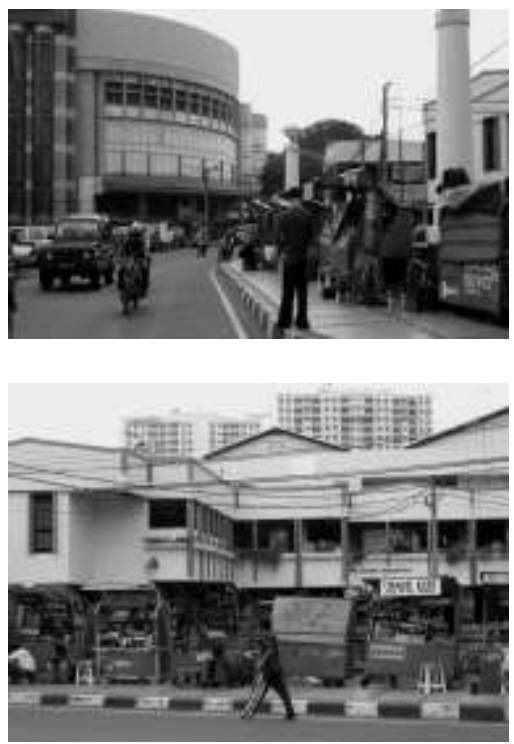

Lokasi : Jl. ABC

Gambar 5 Kegiatan pada pagi hingga siang hari (sekira pk. 08.00-16.00). 


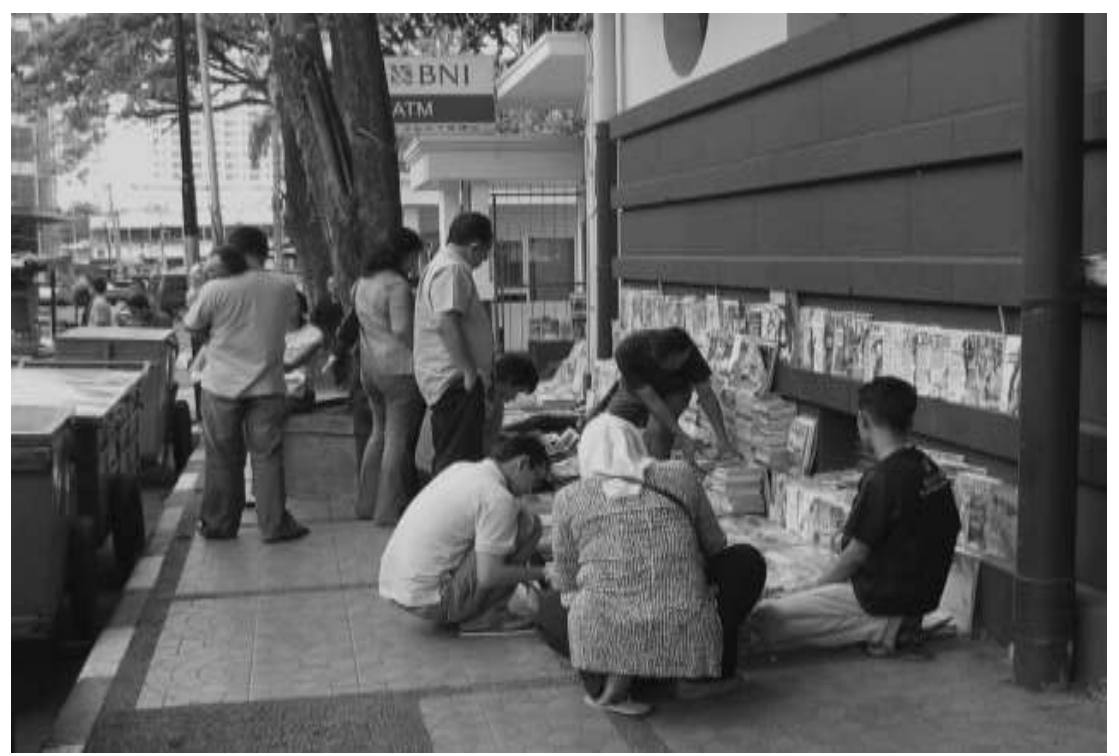

Lokasi : Jl. Cikapundung Timur (foto dari arah sebelah barat Gedung Merdeka mengarah pada pertigaan Jl. ABC)

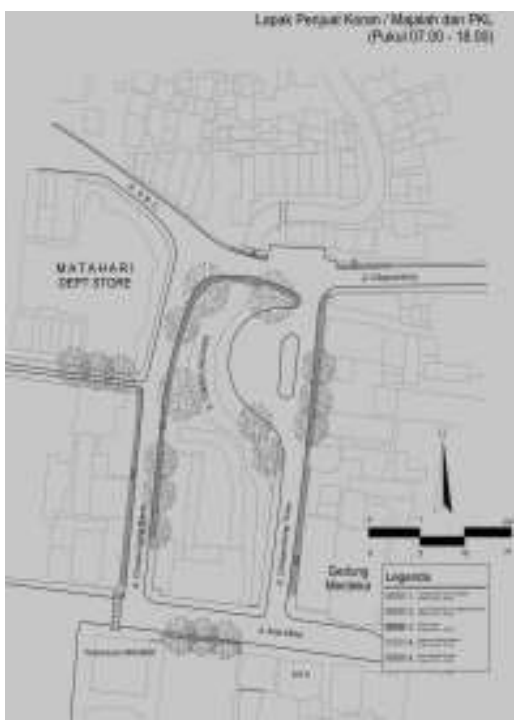

Area tempat berjualan majalah bekas dan baru

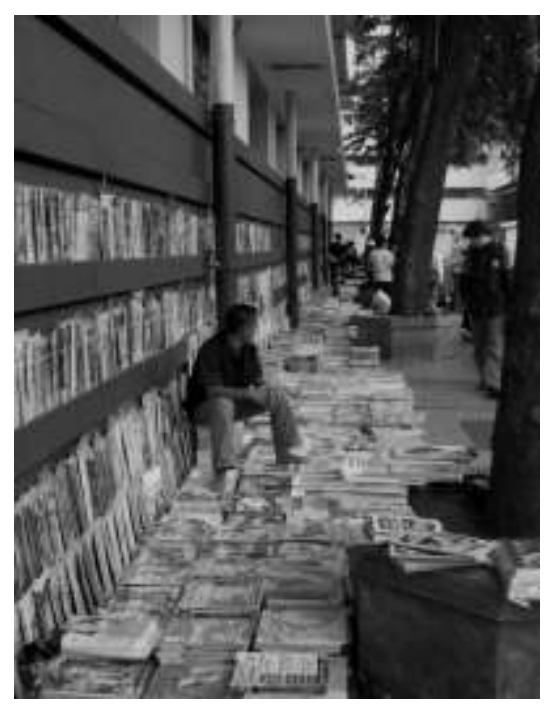

Lokasi : Jl. Cikapundung Timur (foto dari arah sebelah barat Gedung PLN mengarah pada pertigaan Jl. Asia - Afrika)

Gambar 6 Aktivitas perdagangan buku dan majalah (bekas \& baru) (sekitar pk. 08.00-17.00). 


\subsection{Kegiatan pada Siang hingga Sore Hari}

Kegiatan formal perkantoran pada umumnya berlangsung hingga sore hari sekitar pk. 17.00. Kegiatan komersial sebagian ada yang berakhir pada waktu yang sama, sebagian yang lain akan berakhir pada pk.21.00. Demikian halnya dengan aktivitas para pedagang buku/majalah dan pelaku sektor informal lainnya di sekitar area ini. Menjelang sore hari, ketika matahari mulai condong ke barat, sekira pk.04.00 sore hari, aktivitas kembali berganti Terlihat iringiringan gerobak keluar dari sudut-sudut tempat penyimpanan.. Bergerak perlahan menuju sisi-sisi trotoar yang telah bersih dari kegiatan sebelumnya. Trotoar kembali berubah fungsi menjadi area tempat kegiatan restoran jalanan berlangsung.

Suasana kembali berubah; kesibukan di sore hari ini kembali terasa dengan adanya perubahan aktor dengan aktivitas yang berbeda. Tenda-tenda mulai dipasang, peralatan makan di tata, perlengkapan bagi pengunjung seperti meja, kursi dengan cepat dipasang. Sebelum matahari tenggelam di ufuk Barat, terdengar keramaian beberapa remaja yang memanfaatkan kekosongan ruang terbuka Lapangan Cikapundung sebagai arena bermain bola. Rentang waktu yang tidak lebih dari satu jam tersebut dimanfaatkan oleh mereka yang beraktivitas di sekitar area. Menjelang gelapnya malam, kompor-kompor mulai dinyalakan dan kegiatan restoran jalanan siap berlangsung. Terdapat berbagai jenis makanan baik berupa camilan/snack seperti gorengan, martabak, atau jenis makanan "berat" seperti lontong padang, sate ayam, makanan bergaya cina, ayam bakar dan berbagai jenis makanan dan minuman lainnya. Para aktor siap melayani para pelanggan yang datang dari berbagai sudut kota.

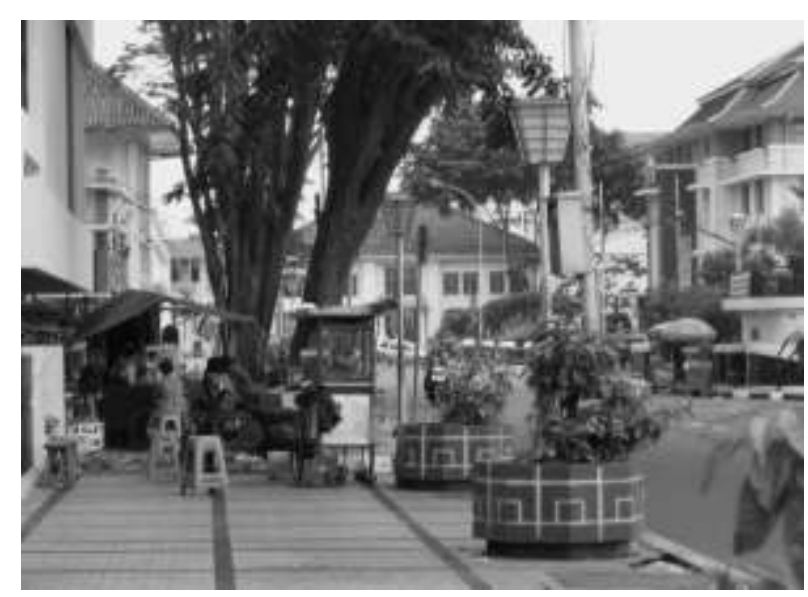

Gambar 7 Aktivitas pada sore hari di sekitar area Lapangan Cikapundung. Lokasi: Jl.Cikapundung Timur (foto mengarah pada pertigaan Jl.Asia-Afrika). 


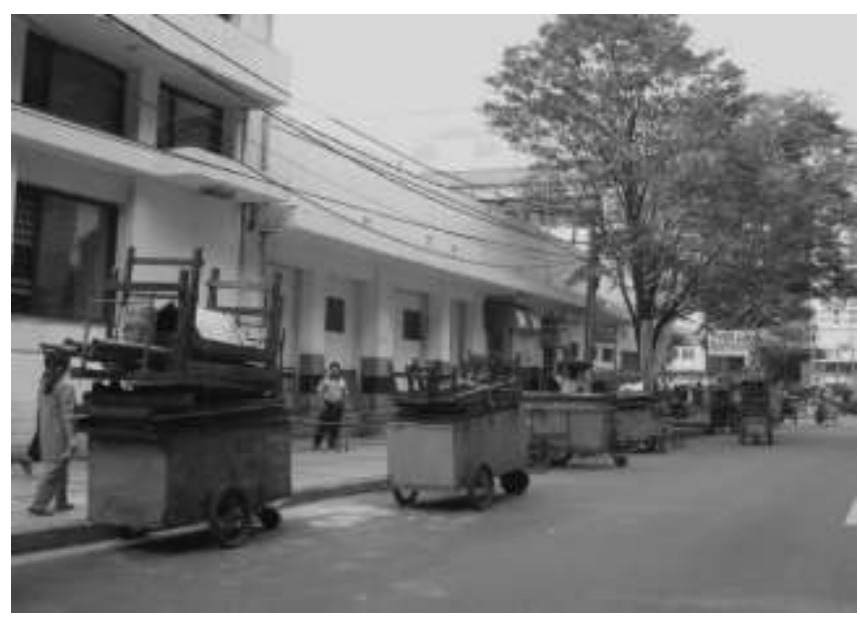

Gerobak mulai berdatangan sekira pk.4.00 sore

Lokasi : Jl.

Cikapundung Barat (foto mengarah pada pertigaan Jl. ABC)

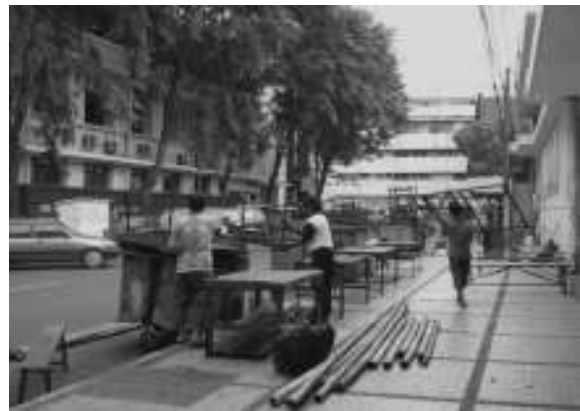

Proses konstruksi

Lokasi : Jl. Cikapundung Barat (foto mengarah pada pertigaan Jl. Asia Afrika)

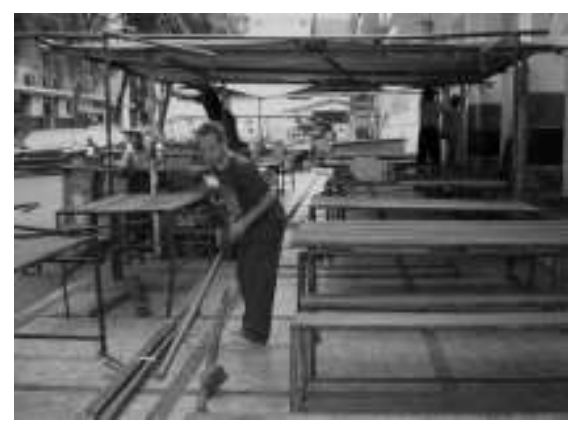

Area trotoar yang telah berubah menjadi restoran

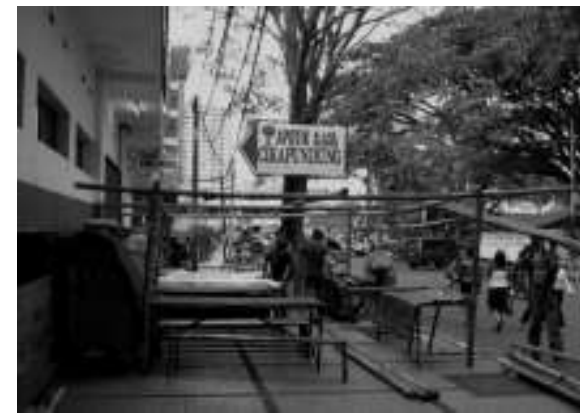

Proses konstruksi

Lokasi : Jl. Cikapundung Barat (foto mengarah pada Jl. ABC)

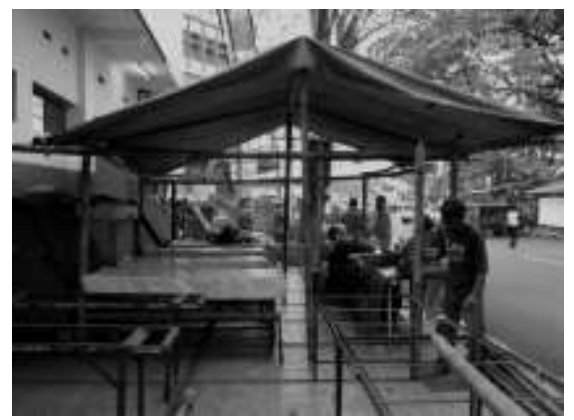

Konstruksi area makan telah selesai dan "konstruksi" dapur sedang disiapkan

Gambar 8 Aktivitas persiapan restoran jalanan malam (dimulai sekira pk. 04.00 sore). 


\subsection{Kegiatan Sore hingga Malam Hari}

Secara umum, aktivitas utama yang terjadi pada rentang waktu ini adalah kegiatan para aktor yang berjualan makanan untuk santap malam. Deretan restoran jalanan ini menempati ruang-ruang yang telah "dibagi" berdasarkan kesepakatan. Pada umumnya mereka yang berjualan di tempat ini merupakan "aktor lama" yang telah berjualan lebih dari sepuluh tahun. Bahkan terdapat beberapa pedagang yang melanjutkan kegiatan orang tuanya dan telah beralih generasi. Kegiatan berlangsung hingga sekira pk.24.00; sebagian ada yang masih bertahan hingga pk.01.00 dini hari.

Sebagai akibat alamiah dari kegiatan ini adalah munculnya para petugas parkir "shift malam". Sebagian badan jalan di sekitar area restoran difungsikan sebagai area parkir. Kemudian Lapangan Cikapundung dan sekitarnya tersebut diisi oleh para aktor yang berbeda.

\subsection{Kegiatan pada Malam hingga Dini Hari}

Kegiatan para pelaku restoran jalanan malam sejak beberapa tahun terakhir diikuti oleh seorang pengelola kantin malam terbuka yang keberadaannya sangat disukai oleh para pelaku kegiatan yang melakukan kegiatan pada malam hingga menjelang dini hari. Kantin ini baru beroperasi mulai pk. 09.00 malam dan berakhir pada keesokan harinya sekira pk. 06.00 pagi.

Kantin ini berada di sebuah lekukan di samping jembatan Cikapundung yang pada siang harinya digunakan sebagai area parkir. Saat pengunjung padat, kantin ini dapat menampung sekira 150 orang dengan duduk di atas kursi plastik. Pengunjung yang hadir memiliki tujuan dan latar belakang berbedabeda. Ada yang mencari makan malam karena sebagian besar restoran pada umumnya telah tutup dan adapula yang bekerja "lembur", atau kaum muda yang gemar mencari hiburan di klub malam.

Pemilik (aktor utama) kantin adalah seorang ibu rumah tangga yang tinggal di dalam kampung Braga. Dibantu suami dan beberapa orang karyawan, kelompok ini menjadi salah satu penggerak aktivitas kehidupan malam salah satu sudut kota Bandung. Suasana yang berbeda dibandingkan pada siang harinya di bentuk oleh aktivitas tersebut dan gelapnya malam. Kegiatan ini pun diikuti oleh munculnya aktor lain; tidak hanya petugas parkir "shift dini hari", melainkan para penjual jasa musik alamiah (pengamen) yang menghibur para pengunjung. Kemeriahan suasana ini seringkali menarik perhatian mereka yang kebetulan melewati area ini pada waktu-waktu tersebut. Sebelum aktivitas ini berakhir, menjelang pk 04.00 pagi, para agen dan loper koran mulai berdatangan. Komunitas ini kerap memanfaatkan keberadaan kantin ini sambil menunggu datangnya kendaraan yang membawa surat-surat kabar dan majalah. 
Demikianlah ruang terbuka lapangan Cikapundung dan sekitarnya yang tidak pernah berhenti berganti suasana dan mewadahi aktivitas berbagai aktor dan berbagai lapisan warga kota.

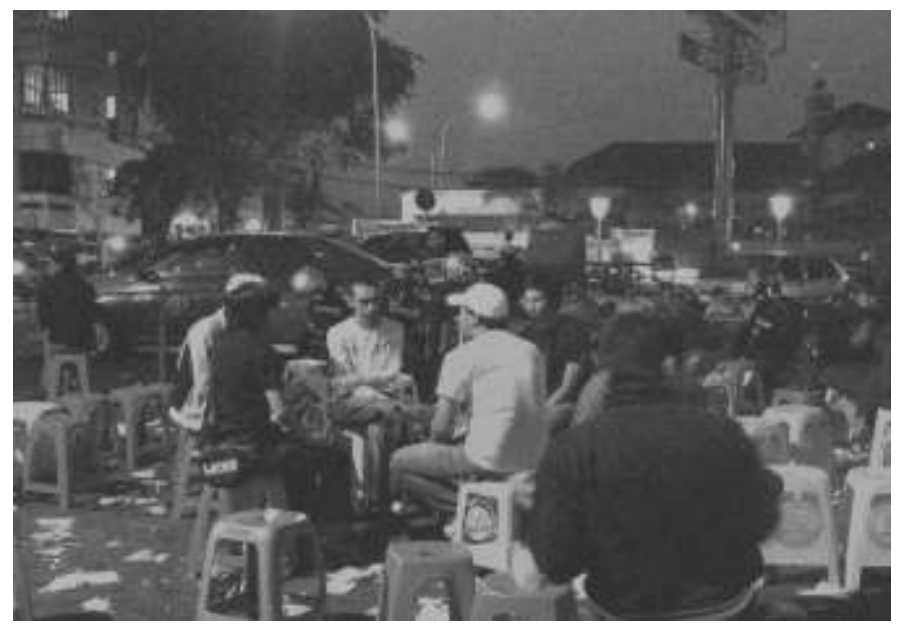

Suasana kantin malam terbuka (sekira pk.03.00 dini hari) Lokasi : Jl. ABC (foto mengarah ke lapangan Cikapundung)

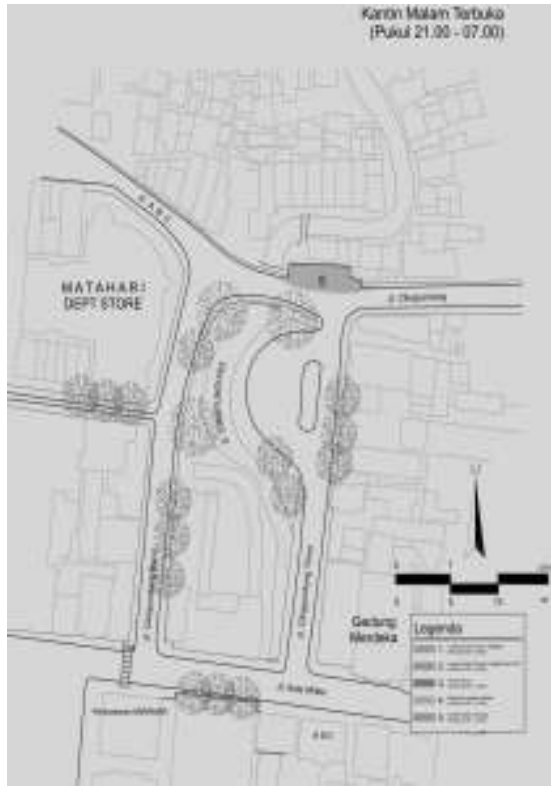

Area yang diarsir (sisi Utara Lapangan Cikapundung) adalah lokasi Kantin Malam Terbuka J1. Asia-Afrika).

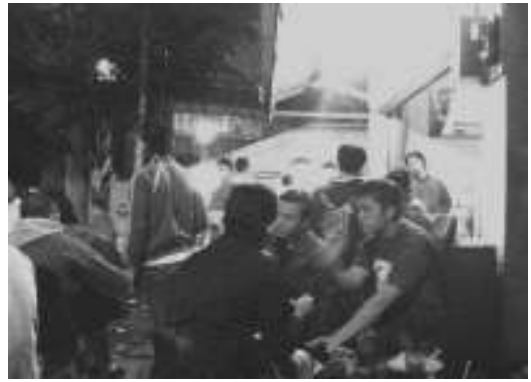

Sisi lain suasana kantin malam terbuka

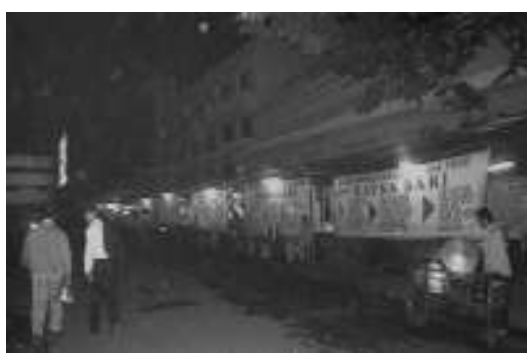

Suasana pada sisi Jl. Cikapundung Barat (foto mengarah pada persimpangan dengan Jl. Asia Afrika).

Gambar 9 Kegiatan Kantin Malam Terbuka dan sekitarnya (sekira pk. 21.0006.00) 


\section{$4 \quad$ Hidden Order dan Hidden Power}

Dalam kasus studi Lapangan Cikapundung, keragaman aktivitas harian merupakan kekuatan yang melandasi keaktifan ruang terbuka tersebut selama 24 jam. Keragaman ini dibentuk dan dikendalikan oleh para aktor yang terlibat di dalamnya yang terpelihara karena interaksi sosial yang dibina secara terus menerus.

Para aktor yang berperan dalam mengendalikan dan mengontrol ruang tersebut antara lain: petugas kebersihan, petugas parkir, pedagang kaki lima, penjual majalah/buku bekas, pemilik warung-warung tenda, pemilik kantin malam, termasuk para aparat (ketua RT, RW setempat) dan "aktor-formal" pegawai pemerintah kota yang memilih untuk selalu "berkoordinasi" dengan para pelaku kegiatan. Penggunaan bersama ruang terbuka secara bergantian ini berlangsung secara perlahan-lahan dan melalui suatu proses yang panjang.

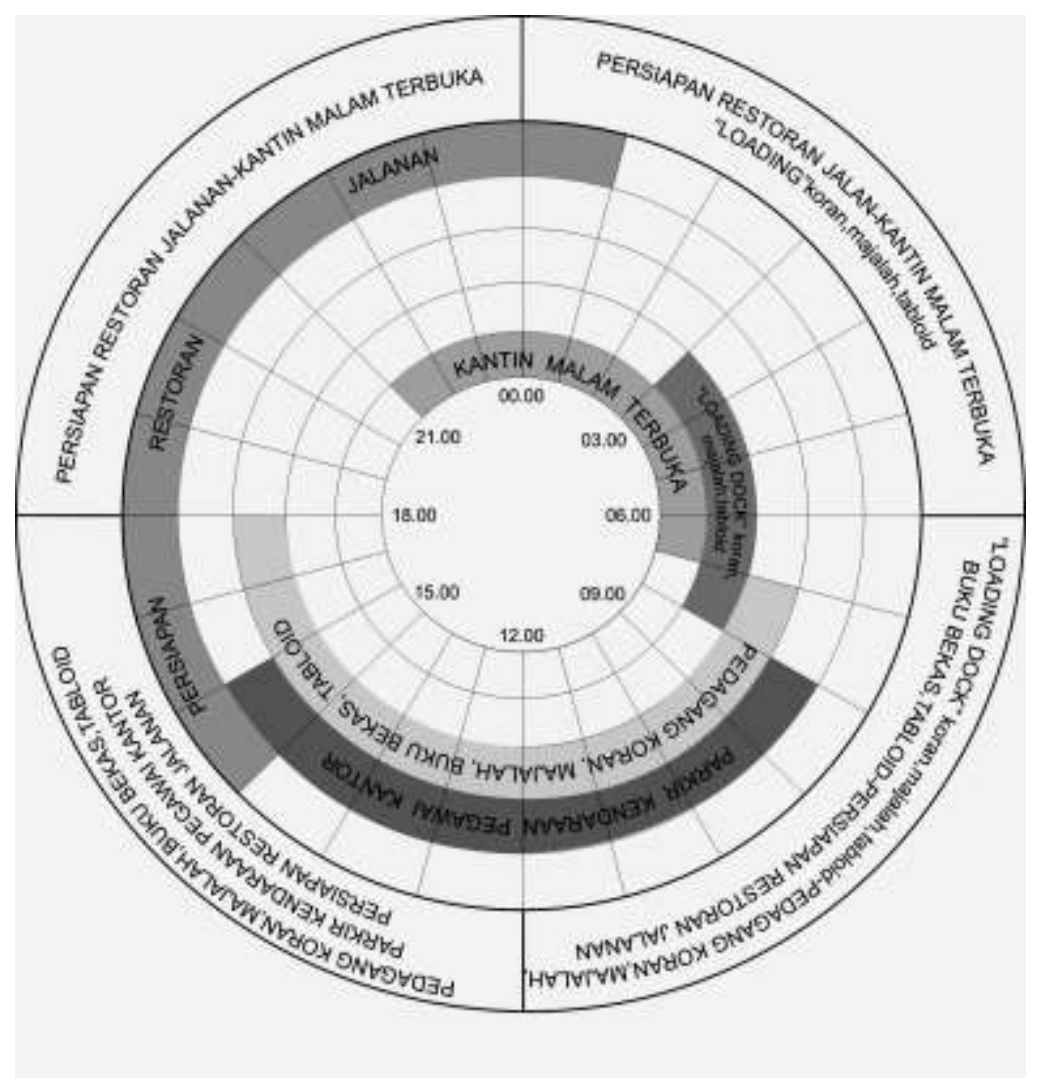

Gambar 10 Diagram siklus aktivitas di sekitar area lapangan Cikapundung. 
Keseluruhan aktivitas yang meliputi: (1) kegiatan bongkar muat surat kabar dan majalah, (2) kegiatan penjualan majalah dan buku bekas, (3) parkir bagi pegawai kantor di sekitarnya, (4) kegiatan restoran jalanan, dan (5) kegiatan kantin malam terbuka yang berlangsung hingga dini hari, disebut Shane [5] sebagai situasi urban yang berbentuk serpihan kegiatan-kegiatan. Jalinan kegiatan ini membentuk sebuah jukstaposisi aktivitas yang tidak pernah berhenti.

Aktivitas yang saling tumpang tindih secara meruang dan secara mewaktu ini, dikendalikan bukan oleh sebuah perangkat manajemen yang khusus dirancang dan direncanakan sejak awal. Proses ini berlangsung secara alamiah dalam kurun waktu berpuluh tahun dengan berbagai perubahan yang terus menerus terjadi. Para aktor sebagai unsur penting yang menghidupkan ruang, memiliki akses langsung terhadap setiap proses pengambilan keputusan.Secara diagramatis, jalinan kegiatan keseharian yang terjadi, secara umum diperlihatkan pada gambar berikut ini.

Berdasarkan diagram di atas terlihat bahwa 5 (lima) kegiatan utama yang menghidupkan area ini jalin menjalin menjadi suatu siklus. Waktu yang paling padat terjadi antara pk.06.00 hingga pk.18.00, ketika terjadi setidak-tidaknya 4 (empat) kelompok kegiatan pada saat tersebut. Sedangkan pada waktu lain, intensitas kegiatan tidak terlalu padat karena hanya terdiri dari 2 (dua) kegiatan saja. Secara meruang, komposisi dan tata letak masing-masing kegiatan telah diperlihatkan pada uraian sebelumnya. Pilihan-pilihan lokasi tersebut juga tidak terjadi sekaligus, melainkan melalui proses berpuluh-puluh tahun. Ruang-ruang yang "dikuasai" pada umumnya merupakan "warisan turun-temurun" dan "hak pengelolaannya" disepakati secara sosial

\section{$5 \quad$ Simpulan}

Ruang publik merupakan wilayah kajian yang multi faset dan perlu mengalami pengamatan ulang secara terus menerus. Persoalan-persoalan di ruang publik tidak pernah dapat melepaskan diri dari persoalan sosial budaya masyarakatnya. Budaya yang menganggap jalan hanya sebagai sarana tempat berpindahnya barang dan jasa akan berbeda dengan masyarakat yang menganggap jalan sebagai ruang sosial-budaya. Sebuah rencana yang mengganggap trotoar hanya untuk dilewati akan berbeda dengan rancangan yang membuka kemungkinan terjadinya interaksi sosial di area pejalan kaki tersebut.

Berdasarkan studi kasus ini, jelaslah bahwa kualitas suatu ruang publik tidak semata-mata ditentukan oleh faktor fisik. Ruang yang dirancang lebih baik secara fisik belum tentu menjadi "tempat yang bermakna"/place bagi warga kotanya. Sebaliknya, ruang publik yang secara fisik "seadanya" dapat menjadi 
tempat yang bermakna (meaningful) jika "dikelola" secara tepat guna, tepat waktu, dan tepat budaya.

Terungkap pula bahwa dibalik "tampilan fisik" yang tak beraturan dan "tak terkontrol", ternyata terdapat pola (order) berupa ritme aktivitas yang disusun berdasarkan kesepakatan sosial antar para aktor yang terlibat di dalamnya. Para aktor ini sekaligus pula berperan sebagai pengendali yang memiliki kekuasaan dalam mengatur berbagai aspek, guna menjamin kesinambungan/keberlanjutannya. Namun pada sisi lain, kondisi tersebut menunjukkan lemahnya peran State (Negara) dalam mengelola sistem-sistem perkotaan, terutama yang menyangkut kepentingan publik. Akibatnya, peran tersebut "diisi" oleh "lembaga-lembaga" non-formal . Di negara berkembang, kondisi di atas hendaknya menjadi pertimbangan dalam proses perancangan ruang publik yang semakin dibutuhkan, terutama di kota kota besar.

\section{Ucapan terima kasih}

Riset ini dibiayai oleh ITB berdasarkan Surat Perjanjian Pelaksanaan Penelitian No: 0023/K01.03.2/PL2.1.5/I/2007, tanggal 10 bulan Januari 2007, Lembaga Penelitian dan Pengabdian Pada Masyarakat.

\section{Referensi}

[1] Chase, J., Crawford, M., Kaliski, J. 1999. Everyday Urbanism, The Monacelli Press, Inc., New York, hal. 8-10.

[2] Crawford, Ibid hal. 9.

[3] De Certeau dalam Crawford. 1999. Everyday Urbanism, The Monacelli Press, Inc., New York, hal.12-13.

[4] Kunto, Haryoto. 1996. Balai Agung di Kota Bandung, PT Granesia, Bandung, hal. 79.

[5] Shane, David Grahame. 2005. Recombinant Urbanism: Conceptual Modeling in Architecture, Urban Design, and City Theory, John Wiley \& Sons Ltd., England, hal 8-11. 